\title{
Water infiltration and time to recharge the profile of three soils Rio Grande do Sul, Brazil
}

\author{
Afranio Almir Righes, Galileo Adeli Buriol, Valduino Estefanel \\ Environmental and Sanitary Engineering of Franciscan University, Santa Maria, Brazil; \\ righes@unifra.br, galileo@unifra.br, valduino@unifra.br
}

Received 2 September 2013; revised 3 October 2013; accepted 8 November 2013

Copyright (C) 2013 Afranio Almir Righes et al. This is an open access article distributed under the Creative Commons Attribution License, which permits unrestricted use, distribution, and reproduction in any medium, provided the original work is properly cited.

\section{ABSTRACT}

The Rio Grande do Sul-RS State, even with average annual rainfall of $1.721 \mathrm{~mm}$, has shown a lack of water in the soil for crop production. The study aimed to determine the variation of annual and seasonal precipitation over the time; determine the year seasons that can provide the recharge of water into the soil profile and estimate the time needed to fulfill the soil pore space with water from effective rainfall with different scenarios of water infiltration. The soil uses were: oxisol; Red Yellow Podzolic and Planosolo Hydromorphic Eutrophic respectively in the North, Centre and South of RS State. We determined the total variation of annual rainfall, mean annual potential evapotranspiration and the time required to refill the soil profile for three infiltration scenarios: with fractions 1/2, 2/3 and $3 / 4$ of effective rainfall. In the regions of Passo Fundo, Santa Maria and Santa Vitóriado Palmar, from 1914 to 2004 there was no reduction in the annual volume of rainfall. Considering that $50 \%$ of soil volume and water storage are met and that the fraction $1 / 2,2 / 3$ and $3 / 4$ of the effective rainfall infiltrates into the soil, the recharging time profile varies from 3.7 to 16.6 years, infiltrating $2 / 3$ range from 1.8 to 6.6 years and infiltrating $3 / 4$ of effective precipitation range from $\mathbf{1 . 2}$ to 5.1 years, the time required to refill the entire soil porous space. The recovery of water storage in the soil profile must occur mainly during winter, followed by spring and fall.

Keywords: Macro Porosity; Rainfall; Drought; Soil Water Storage

\section{INTRODUCTION}

In Rio Grande do Sul (RS) State in Brazil, during the colder months of the year, all of the territory has excess water, and in the warmer months, especially in December, January, and February, droughts occur.

These conditions are more frequent in the southern area of the state [1]. Normal medium rainfall data indicate that in the southern part of the state, the probability of potential evapotranspiration is higher than the total monthly rainfall in the summer months, approximately $70 \%$, but the northern area showed no water deficit [2]. However, despite these results, the deficiencies of soil water for crops, even in soils more than $8 \mathrm{~m}$ deep and with high water storage capacity, appear to have increased, especially in the northern part of the state. In this part of the state, at Passo Fundo, the soil type is oxisol $[3,4]$. The soil macroporosity layer of $0.025 \mathrm{~m}$ to 0.15 $\mathrm{m}$ depth has only $10 \%$ of volume in macropores [5].

The mean total annual rainfalls for the north, center, and south of the state are approximately 2000, 1700, and $1200 \mathrm{~mm}$, respectively [6,7]. The normal values of average annual potential evapotranspiration range from approximately $600 \mathrm{~mm}$ in Sierra Northeast to $1000 \mathrm{~mm}$ in the Lower Valley of Uruguay [8]. Considering these values, the areas probably would not have water deficits if all, or most, of the volume of water precipitated was stored in the soil and the plant root system could extract it [9]. Thus, other contributing factors are present, so that within periods of the same number of days without precipitation, soil water deficits occur with more intensity.

The intensive soil is mobilized by mechanical equipment, such as plows and harrows, that occurred in the 1970s accelerated the soil structure degradation and increased soil compaction. The intensive soil mobilization changed its original structure by fractionation of the aggregates into smaller units, reducing the percentage of organic matter and the percentage of macropores and increasing the soil bulk density and the volume of micropores. As a consequence, there is a reduction in the soil water infiltration rate, resulting in increased runoff [10-12]. A similar situation has also occurred in areas 
used by livestock with a high number of animals per area. Being trampled by the animals has compacted on the soil surface, with hydrological results similar to those of heavily exploited agricultural areas. Intensive traffic of agricultural machines and animal trampling in areas with a crop-livestock system have increased soil compaction. In this system of management, the use of heavy machinery must be prevented and animals must be removed from the common crop-livestock area when the soil water content is over the range of friability [13].

The biggest problems of water erosion, siltation of rivers, and soil loss in the RS occurred in the 1970s. By that time, different mechanical techniques were used to control soil erosion, such as terraces, sub-soiling, and scarifications. These techniques were not sufficient to control soil erosion satisfactorily. Finally, the no-tillage system, ideal for tropical regions, was introduced. However, when implemented on degraded soils with impediment layers (compacted layers with a low rate of water infiltration) located below the mobilized layer in the conventional tillage system, the no-tillage system reduced water infiltration into the soil.

The effectiveness of no-tillage in controlling soil erosion led the farmers in the northern region of the RS to almost entirely removing the existing terraces in their crops and fields, because of the increased operating capacity of agricultural machinery and even sowing in the slope direction. However, the farmers have not used crop rotation in the no-tillage system. The "foot plow" was not eliminated and remains in use today. Thus, the notillage system has effectively controlled soil loss, but the water losses by runoff are even higher than in the conventional tillage system. The losses of nutrients and organic matter in runoff sediment in the no-tillage system are higher than those in the same soil with conventional tillage [14]. Low values of infiltration dramatically reduce the water storage in the soil and aquifer recharge, increasing runoff and flooding. In the north regions of the RS, in the oxisols mapping units Passo Fundo and Santo Angelo, most wells with depths between 10 and 15 $\mathrm{m}$ are dry during drought periods, and even after heavy rainfall in the summer time, the water levels do not return to normal. This shortage is evident that the macropores are not filled with water from rainfall and, as a consequence, there is little free gravity water to feed the wells, rivers, and strands. Another finding of this effect can be seen in road cuts in deep soils, that, during heavy rainy periods, after only a few hours, there is no more water to be gravity drained from the soil profile.

This study was conducted in three soil-mapping units in three regions of the RS, with the following objectives: 1) determine the variation of annual and seasonal precipitation over time, 2) determine which seasons of the year effective rainfall can refill the soil water profile, and
3) estimate the time required to fill the pore space of the soil profile with water available from the effective rainfall with different scenarios of water infiltration into the soil.

\section{METHODS}

The study was conducted in the north of the RSon the Passo Fundosoil-mapping unit, classified as oxisol;in the center of the RS on the São Pedro soil-mapping unit, classified as red-yellow podzolic loam texture; and in the south of the RS onthe Vacacaí soil-mapping unit, classified as planosolo hydromorphic eutrophic, used with flood-irrigated rice $[3,4]$.

The study of temporal rainfall was done using monthly and annual totals data from three weather stations: Passo Fundo (latitude $28^{\circ} 15^{\prime} 39^{\prime \prime S}$, longitude $52^{\circ} 24 ' 33^{\prime \prime} \mathrm{W}$, and altitude $678 \mathrm{~m}$ ), Santa Maria (latitude $29^{\circ} 41^{\prime 25}$ "S, longitude 53 48'42"W, and altitude $138 \mathrm{~m}$ ), and Santa Vitória do Palmar (latitude $33^{\circ} 31^{\prime} 14^{\prime \prime} \mathrm{S}$, longitude 53 $21^{\prime} 47^{\prime \prime} \mathrm{W}$, and altitude $6 \mathrm{~m}$ ), located, respectively, in the north, center, and south of the RS. Data were obtained from the Eighth District of Meteorology (8th DISME) of the National Institute of Meteorology (INMET), in Porto Alegre. The observation period of rainfall for the three sites was 1914 to 2004. From the monthly totals, annual and seasonal monthly averages were obtained, taking into consideration the summer months of December, January, and February; the autumn months of March, April, and May; the winter months of June, July, and August; and the spring months of September, October, and November.

Atthe three weather stations, the rainfall was found to be of type iso-hygro, the rain is distributed similarly over the 12 months of the year, and the Spearman correlation coefficient showed that the rainfall is homogeneous [15]. This coefficient shows that the rainfall is homogeneous for the three stations, not that the system is iso-hygro. The iso-hygro quality was checked visually. In a preliminary exploratory analysis, as suggested by the World Meteorological Organization [16], scatter diagrams were plotted, relating the calendar year to the original data and also to the centered moving average, with a period of 9 years. To verify the existence of abrupt changes in each weather station, the historical data series was divided into two periods and the Mann-Whitney test applied, comparing the averages of these periods. The dividing point was held year to year from 1918 to 1998, involving 81 test applications. The year in which the test showed a lower minimum level of significanceMLSwas considered the date of abrupt change. A year in which no test had $p \leq$ 0.05 was considered a year of no abrupt changes.

The Spearman correlation coefficient and the MannWhitney nonparametric test were used because rainfall data do not meet all the requirements of parametric 
equivalent tests, particularly the assumption of independence of errors [17].

The potential evapotranspiration (PET) was calculated by the model of Thornthwaite and Mather [18]. For this, the average monthly temperatures for the period 19311960 were used [7]. The effective rainfall to refill the soil profile was obtained by the difference between the rainfall computed for the period and average PET, the normal value for the same period.

To estimate the time needed to fill the soil profiles with water from the effective rainfall, we used precipitation data and mean values of the soil physical parameters for water and dates from its mapping-unit descriptions. These values were obtained from the reconnaissance soil survey of the RS [4] and experiments performed in the areas under study $[5,19]$. The total porosity $(T p)$, in\% of volume was calculated by Equation (1):

$$
T p=100-\left[\frac{(100 \times S d)}{P d}\right],
$$

where $S d$ is the soil bulk density, and $P d$ is the particle density.

The maximum storage of water for each mapping unit, Equation (2), was determined by considering the depth of the soil profile:

$$
V=\frac{(F c-W p)}{100} S d \cdot d \cdot S,
$$

where $V$ is the maximum storage of water $\left(\mathrm{m}^{3} \cdot \mathrm{ha}^{-1}\right), F_{C}$ is field capacity (\% mass), $W p$ is wilting point (\% mass), $S d$ is soil bulk density, $S$ is the area $\left(\mathrm{m}^{2}\right)$, and $d$ is soil depth (m).

To estimate the time required to refill the pore space of the soil profile it was assumed that $50 \%$ of the maximum soil water storage capacity (field capacity less wilting point) was already filled with water. Three scenarios ofwater infiltration into the soil were simulated using $1 / 2$, $2 / 3$, and $3 / 4$ of the normal average effective precipitation. The volume needed to fill the macropores $\left(V_{\text {macro }}=\right.$ pore space between field capacity and \% of soil water saturation) was calculated, using Equation (3):

$$
V_{\text {macro }}=\frac{(T p-F C)}{100} \times d \times S,
$$

where $V_{\text {macro }}$ is the volume of water needed $\left(\mathrm{m}^{3} \cdot \mathrm{ha}^{-1}\right)$ to fill the soil macropores, $T p$ is the total porosity (\% volume), $F C$ is field capacity (\% vol.), $d$ is profile depth $(\mathrm{m})$, and $S$ is area $\left(\mathrm{m}^{2}\right)$. If the area $S$ is $10,000 \mathrm{~m}^{2}$, to find the values in depth of water $h(\mathrm{~mm})$ the value $V_{\text {macro }}$ must be divided by 10 .

\section{RESULTS AND DISCUSSION}

Figure 1 shows the total annual rainfall scatter points for the counties of Passo Fundo, Santa Maria, and Santa Vitóriado Palmarduring the period of 1914-2004 and average normal values for PET. It shows that for Santa Maria and Passo Fundo, only in 1917 was the average PET higher than the total annual rainfall. For Santa Vitóriado Palmar PET was higher than average rainfall in 4 years. The results in Figure 1 indicate that the volume of water from rainfall is not the limiting factor for the lack of water in the soil.

When the existence of sudden changes in precipitation curves for two observation periods were studied, a change in the volume of precipitation was found in or near the year 1981 .

After 1981, the averages were higher for the three weather stations: Passo Fundo, 241.5 mm; Santa Maria, 219.7 mm; and Santa Vitóriado Palmar, 129.1 mm (Table 1). From these results, it is evident that in recent years no reduction in the volume of rainfall occurred in the three regions of the RS, although the impacts of drought periods on water shortages have been higher.

The drought effects that occur today are extremely more impactfulon crop yields and on base flow of the riversthan formerly occurred because in that time more water was probably stored in the soil profile. To analyze this impact, Table 2 presents the average values of physical parameters of the soil and water in the three soilmapping units used in this work, which form the basis to simulate future scenarios on the time required for the soil profile to recover the saturated flow to sustain the streams and rivers.

In Table 2, the high value for total depth of water needed to saturate the soil profile for the Passo Fun- dosoil-mapping unit is because of the 8-meter depth and high percentage of water storage $(10 \%)$. The data show that if the water infiltration rate is not the limiting factor, this soil can store the total amount of one year's rainfall at once. However, that is not possible because of low infiltration. The estimation of the time required to fill the pore space of the soil profile with water available from the effective rainfall with different scenarios of water infiltration into the soil can be found in Table 3 .

When PET values were higher than the effective rain-

Table 1. Average total annual rainfall for the three weather stations in the RS during the periods of 1914-1981 and 19822004.

\begin{tabular}{cccc}
\hline \multirow{2}{*}{ Weather Stations } & $1914-1981$ & $1982-2004$ & Difference \\
\cline { 2 - 4 } & \multicolumn{3}{c}{$(\mathrm{mm})$} \\
\hline Santa Maria & 1672.2 & 1891.9 & 219.7 \\
Passo Fundo & 1697.1 & 1938.6 & 241.5 \\
Santa Vitória do Palmar & 1204.4 & 1333.5 & 129.1 \\
Average & 1524.8 & 1721.3 & 196.7 \\
\hline
\end{tabular}




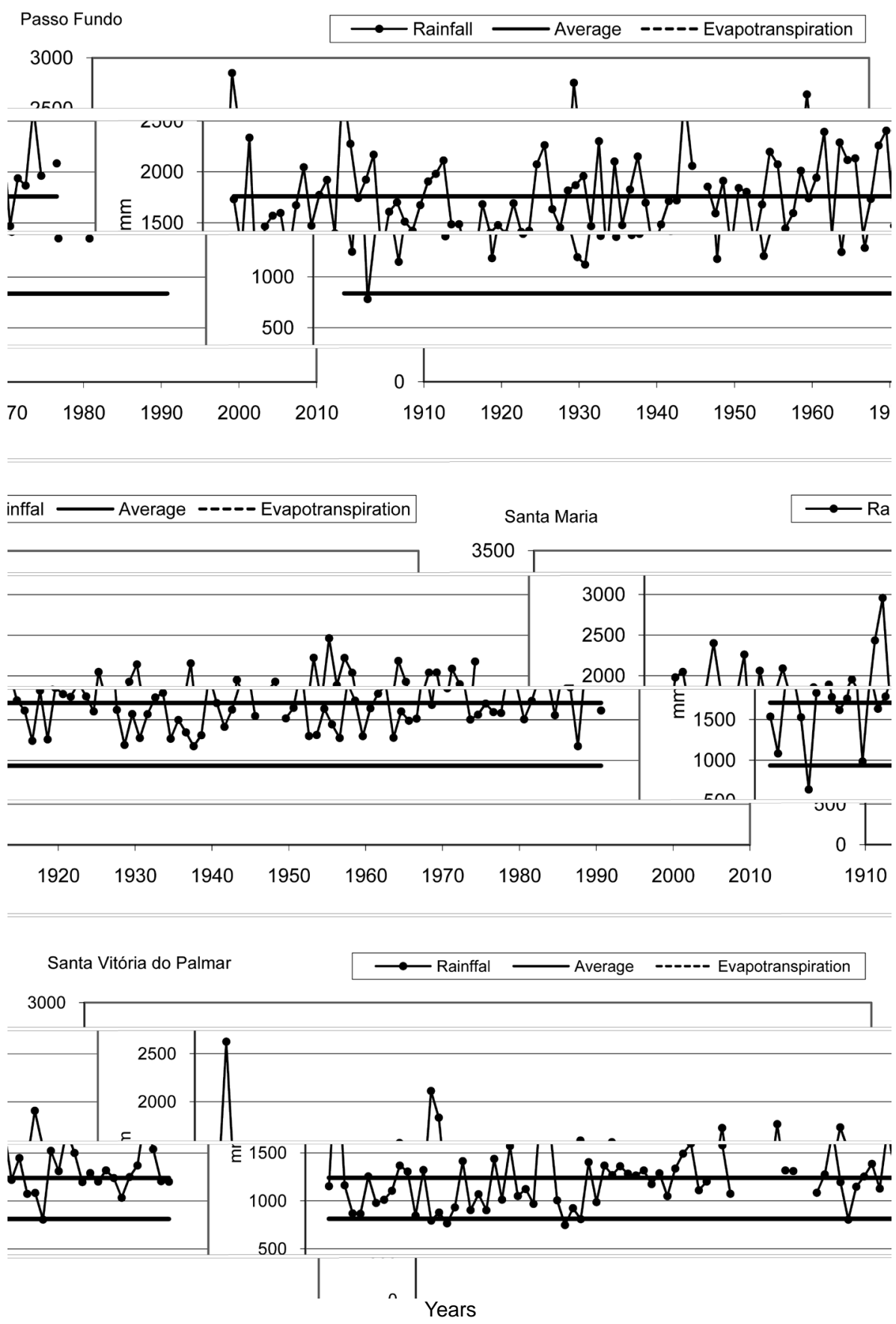

Figure 1. Scatter plots of the total annual rainfall and average annual PET from the meteorological stations of Passo Fundo, Santa Maria, and Santa Vitóriado Palmar.

fall, it was assumed that there was no water storage in the soil. The recharge of ground water throughout the year occurs during the winter, followed by spring and autumn, with reversing spring through autumn in the Passo Fundo region because of higher values of normal annual rainfall.

The number of years required to saturate the soil profile can be seen in Figure 2. In the Passo Fundosoilmapping unit, considering a scenario in which $1 / 2$ of the effective rainfall infiltrates the soil, it would take 16.6 years to fill the pores with water. This observation probably explains why the current droughts have a greater impact on the availability of water in rivers and on slopes compared with the droughts that occurred before the 1940s. The soil macroporesunder current conditions are practically empty.

In periods of drought, reducing recharge of macropores has a direct impact on water availability in rivers 
Table 2. Average values of soil physics and hydric parameters of soil-mapping units of Passo Fundo oxisols, Vacacaí planosolo hydromorphic eutrophic, and São Pedro podzólico hapludox.

\begin{tabular}{cccc}
\hline & & County region & \\
Physical parameters ${ }^{1}$ & Passo Fundo & Santa Vitória do Palmar & Santa Maria \\
\cline { 2 - 4 } Soil-mapping unit & Passo Fundo & Vacacaí & São Pedro \\
\hline Depth of soil profile (m) & 8.00 & 1.00 & 3.00 \\
Field capacity (\% mass) & 24.00 & 15.00 & 19.00 \\
Wilting point (\% mass) & 14.00 & 7.00 & 1.00 \\
Soil bulk density & 1.24 & 1.52 & 2.63 \\
Particle density & 2.69 & 2.61 & 46.39 \\
Total porosity (\% vol.) & 53.90 & 41.76 & 26.79 \\
Microporosity (\% vol.) & 29.76 & 18.96 & 19.60 \\
Macroporosity at field capacity (\% vol.) & 24.14 & 121.60 & 465.30 \\
Maximum storage in the soil profile (mm) & 992.00 & 60.80 & 232.65 \\
Depth of water (50\%); maximum storage (mm) & 496.00 & 189.62 & $\mathbf{2 5 0 . 4 2}$ \\
Depth of water to fulfill the soil macroporosity (mm) & 1931.47 & $\mathbf{2 4 2 7 . 4 7}$ & 587.93 \\
Total depth of water to saturate the soil profile (mm) & & $\mathbf{8 2 0 . 5 8}$ \\
\hline
\end{tabular}

${ }^{1}$ Source: The values of soil physical parameters used are the average results from published research papers [5,8,19].

Table 3. Water storage in the soil, normal and effective rainfall, PET, and net storage of water in the soil for the seasons, with three scenarios and estimation of infiltration recharge of the pore space for the Passo Fundo (oxisols), São Pedro (podzolic hapludox) and Vacacaí (eutrophic planosolo hydromorphic) mapping units.

\begin{tabular}{|c|c|c|c|c|c|c|}
\hline \multirow{2}{*}{$\begin{array}{l}\text { Simulated } \\
\text { Scenarios }\end{array}$} & \multirow{2}{*}{ Mapping Unit/Parameters } & \multicolumn{4}{|c|}{ Seasons of the Year } & \multirow{2}{*}{$\begin{array}{c}\text { Total } \\
\text { Annual }\end{array}$} \\
\hline & & Spring & Summer & Autumn & Winter & \\
\hline \multicolumn{2}{|r|}{ Passo Fundo Soil } & \multicolumn{4}{|c|}{$(\mathbf{m m})$} & \\
\hline \multirow{6}{*}{$\begin{array}{l}1 / 2 \text { of the } \\
\text { precipitation } \\
\text { infiltrates }\end{array}$} & Total depth of water to saturate the soil profile (mm) ${ }^{*}$ & - & - & - & - & 2427.5 \\
\hline & Normal rainfall (mm) & 489.2 & 439.9 & 392.8 & 433.6 & 1755.5 \\
\hline & PET (mm) & 213.4 & 325.3 & 191.6 & 107.0 & 837.3 \\
\hline & 1/2 Rainfall (mm) & 244.6 & 219.9 & 196.4 & 216.8 & \\
\hline & Net storage in the soil (mm) & 31.2 & 0.0 & 4.8 & 109.8 & 145.8 \\
\hline & Time to saturate the soil profile (years) & & & & & 16.6 years \\
\hline \multirow{3}{*}{$\begin{array}{l}2 / 3 \text { of the } \\
\text { precipitation } \\
\text { infiltrates }\end{array}$} & 2/3 Rainfall (mm) & 326.1 & 293.3 & 261.9 & 289.1 & $1,170.4$ \\
\hline & Net storage in the soil (mm) & 112.7 & 0.0 & 70.3 & 182.1 & 335.0 \\
\hline & Time to saturate the soil profile (years) & & & & & 6.6 years \\
\hline \multirow{3}{*}{$\begin{array}{l}3 / 4 \text { of the } \\
\text { precipitation } \\
\text { infiltrates }\end{array}$} & 3/4 Rainfall (mm) & 366.9 & 329.9 & 294.6 & 325.2 & \\
\hline & Net storage in the soil (mm) & 153.5 & 4.7 & 103.0 & 218.2 & 479.4 \\
\hline & Time to saturate the soil profile (years) & & & & & 5.1 years \\
\hline \multicolumn{7}{|c|}{ São Pedro Soil } \\
\hline & Total depth of water to saturate the soil profile $(\mathrm{mm})^{*}$ & - & - & - & - & 820.6 \\
\hline & Normal rainfall (mm) & 428.8 & 416.1 & 430.3 & 426.8 & 1702.0 \\
\hline
\end{tabular}




\begin{tabular}{|c|c|c|c|c|c|c|}
\hline & $\operatorname{PET}(\mathrm{mm})$ & 221.9 & 385.0 & 216.3 & 111.0 & 934.2 \\
\hline \multirow{3}{*}{$\begin{array}{l}1 / 2 \text { of the } \\
\text { precipitation } \\
\text { infiltrates }\end{array}$} & 1/2 Rainfall (mm) & 214.4 & 208.1 & 215.2 & 213.4 & \\
\hline & Net storage in the soil (mm) & 0.0 & 0.0 & 0.0 & 102.4 & 102.4 \\
\hline & Time to saturate the soil profile (years) & & & & & 8.0 years \\
\hline \multirow{3}{*}{$\begin{array}{l}2 / 3 \text { of the } \\
\text { precipitation } \\
\text { infiltrates }\end{array}$} & 2/3 Rainfall (mm) & 285.9 & 277.4 & 286.9 & 284.5 & \\
\hline & Net storage in the soil (mm) & 64.0 & 0.0 & 70.6 & 173.5 & 308.1 \\
\hline & Time to saturate the soil profile (years) & & & & & 2.7 years \\
\hline \multirow{3}{*}{$\begin{array}{l}3 / 4 \text { of the } \\
\text { precipitation } \\
\text { infiltrates }\end{array}$} & 3/4 Rainfall (mm) & 321.6 & 312.1 & 322.8 & 320.1 & \\
\hline & Net storage in the soil (mm) & 99.7 & 0.0 & 106.4 & 209.1 & 415.2 \\
\hline & Time to saturate the soil profile (years) & & & & & 2.0 years \\
\hline \multicolumn{7}{|c|}{ Vacacaí Soil } \\
\hline \multirow{6}{*}{$\begin{array}{l}1 / 2 \text { of the } \\
\text { precipitation } \\
\text { infiltrates }\end{array}$} & Total depth of water to saturate the soil profile $(\mathrm{mm})^{*}$ & - & - & - & - & 250.4 \\
\hline & Normal rainfall (mm) & 280.6 & 290.3 & 326.4 & 324.0 & 1221.3 \\
\hline & PET (mm) & 190.0 & 325.0 & 204.0 & 94.0 & 813.0 \\
\hline & 1/2 Rainfall (mm) & 140.3 & 145.1 & 163.2 & 162.0 & \\
\hline & Net storage in the soil (mm) & 0.0 & 0.0 & 0.0 & 68.0 & 68.0 \\
\hline & Time to saturate the soil profile (years) & & & & & 3.7 years \\
\hline \multirow{3}{*}{$\begin{array}{l}2 / 3 \text { of the } \\
\text { precipitation } \\
\text { infiltrates }\end{array}$} & 2/3 Rainfall (mm) & 187.1 & 193.5 & 217.6 & 216.0 & \\
\hline & Net storage in the soil (mm) & 0.0 & 0.0 & 13.6 & 122.0 & 135.6 \\
\hline & Time to saturate the soil profile (years) & & & & & 1.8 years \\
\hline \multirow{3}{*}{$\begin{array}{l}3 / 4 \text { of the } \\
\text { precipitation } \\
\text { infiltrates }\end{array}$} & 3/4 Rainfall (mm) & 210.5 & 217.7 & 244.8 & 243.0 & \\
\hline & Net storage in the soil (mm) & 20.5 & 0.0 & 40.8 & 149.0 & 210.3 \\
\hline & Time to saturate the soil profile (years) & & & & & 1.2 years \\
\hline
\end{tabular}

*Data taken from Table 2.

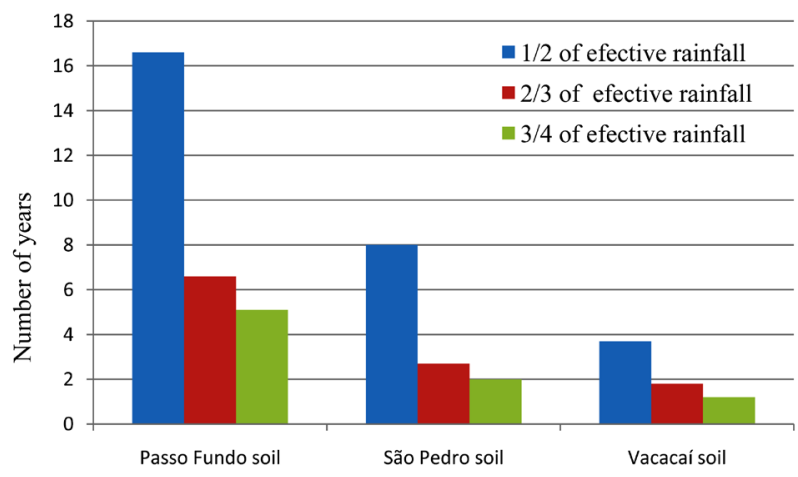

Figure 2. Number of years with normal rainfall necessary to saturate the soil profile of the Passo Fundo, São Pedro, and Vacacaí mapping units for three scenarios of infiltration, $1 / 2$, $2 / 3$, and $3 / 4$ of the effective rainfall.

and reservoirs. Limited recharging incapacitates these environments, making them unable to resist the climatic oscillations that were evaluated by analysis of the time series of rainfall. The storage capacity depends on soil water infiltration, pore space, and the depth of the soil profile. Thus, the stability of the flow in rivers in summertime depends more on storage in deep soils (oxisols) than in lowland soils (planosols).

\section{CONCLUSIONS}

1) In the north, center, and south regions of Rio Grande do Sul State, based on the data of normal rainfall in Passo Fundo, Santa Maria, and Santa Vitória do Palmar between 1914 and 2004, there is no reduction in the annual volume of rainfall.

2) During the summer, the three simulated conditions showed that there is not enough recharge of soil macropores. The recovery of water storage in the soil profile must occur mainly in winter, followed by the spring and fall seasons.

3) In the simulation scenario, infiltrating $1 / 2,2 / 3$, and 
3/4 of effective rainfall shows that the time needed to refill the porous spaces is 16.6, 6.6, and 5.1 years in Passo Fundo soil, is 8.0, 2.7, and 2.0 years in São Pedro soil, is $3.7,1.8$, and 1.2 years in Vacacaí soil, respectively.

\section{REFERENCES}

[1] Buriol, G.A., Estefanel, V., Saccol, A.V., Heldwein, A.B. and Schneider, F. (1980) Possibility occurrence of available soil water in the state of Rio Grande do Sul. Journal of Rural Sciences Center, 10, 1-141.

[2] Avila, A.M.H. (1994) Rainfall regime in the state of Rio Grande do Sul based on long-term series. Dissertation, UFRGS, Faculty of Agronomy, UFRGS Porto Alegre, 75 p.

[3] Brazil Ministry of Agriculture (1973) Reconnaissance soil survey of the state of Rio Grande do Sul Recife. Technical Bulletin, 30, 431.

[4] Embrapa (1999) Brazilian system of soil classification. Production Information Service, Brasilia, 412 p.

[5] Righes, A.A., Nishijima, T., Denardin, J.E., Kochhann, R. A. and Garcia, S.M. (2002) Vertical mulching and runoff inno-tillage system. XIV Brazilian Meeting of Management and Conservation of Soil and Water, Cuiabá.

[6] Machado, F.P. (1950) Contribution to the study of the climate of Rio Grande do Sul. Brazilian Institute of Geography and Statistics, Rio de Janeiro, 91 p.

[7] Agronomical Research Institute (1989) Agroclimatic Atlas of the State of Rio Grande do Sul Porto Alegre: Secretariat of Agriculture and Supply, 1, 102 p.

[8] Ministry of Agriculture (1972) Water Balance of Brazil. National Department of Meteorology, 94 p.

[9] Righes, A.A. (2002b) Water: Sustainability, use and availability for irrigation. Science and Environment, 21, 90-
102.

[10] Bertol, I., Beutler, J.F., Milk, D. and Batistela, O. (2001) Physical properties of a humic cambisol affected by the type of soil management. Scientia Agricola, 58, 555-560. http://dx.doi.org/10.1590/S0103-90162001000300018

[11] Denardin, J.E. (1992) Soil: Formation anddegradation. In: Marcantonio, G., Ed., Soilsand irrigation, UFRGS/FEDERACITE, Porto Alegre, 13-28.

[12] Spera, S.T, dos Santos, H.P., Fontaneli, R.S., Kochhann, R.A., Denardin, J.E. and Spera, M.R.N. (2002) Soil compaction in southern Brazilian oxisols under no-till system. In: International Conference on Land Degradation and Meeting of The IUSS Sub-commission C-Soil and Water Conservation, Rio de Janeiro, 1-3.

[13] Albuquerque, J.A., Sangoi, L. and Ender, M. (2001) Effects of crop/livestock integration in soil physical properties and characteristics of corn. Brazilian Journal of Soil Science, 25, 717-723.

[14] Denardin J.E., Kochhann, R.A. and Righes, A.A. (2005) Vertical mulching: Technical management of runoff in tillage. Tillage Magazine, 14, 37-39.

[15] Pashiardis, S. (2009) Trends of precipitation in Cyprus rainfall analysis for agricultural planning. www.fao.org/rd/climagrimed/pdf/ws01 08.pdf

[16] WMO (2000) Detecting trends and other changes in hydrological data. World Meteorological Organization (WMO/TD No. 1013), Geneva, 157 p.

[17] de Campos, H. (1983) Non-parametric experimental statistical. 4th Edition, ESALQ, Piracicaba, 349 p.

[18] Thornthwaithe, C.W. and Mather, J.R. (1955) Water balance climatology. Publications in Climatology, 8, 1-104.

[19] Peraza, J.E.S. (2003) Water retention and pedofunctions for soils of Rio Grande do Sul. Masters Thesis, Graduate Program in Agricultural Engineering, Federal University of Santa Maria, Santa Maria, 117 p. 